\title{
USING FILMS TO TEACH SOCIAL WELFARE POLICY
}

\author{
Debra Anderson \\ Carol Langer \\ Rich Furman \\ Kim Bender
}

\begin{abstract}
Because social welfare policy tends to be among the least-preferred courses in the social work curriculum, using contemportry films to atugment the course content may help students gain awateness of the nature of the relationship between micro- and macro-level social work. Films may also help to bring abstract policy concepts into a more grounded and focused format. The purpose of this article is to explore the use of contemporary film in teaching social welfare policy courses by presenting three fims as case examples along with suggested disctussion questions for edch. The article concludes by discussing a framework and criteria for the selection and use of flims for social work curvicula.
\end{abstract}

Key Words: Social welfare policy, contemporary film, social work pedagogy

\section{INTRODUCTION}

Aany social work students complain that social welfare policy courses are "dull I and boring" (Dobelstein, 2003, p. 6), while others express feeling overwhelmed by the complex landscape of social welfare problems (Gilbert \& Terrell, 2002); still others express feelings of inadequacy in tackling often-intractable social problems (Anderson, in press). Students' disinterest in policy combined with their feelings of inadequacy in tackling macro-level problems challenge social welfare policy faculty to offer substantive supportive curricula to help students to master policy-related knowledge and skills.

Local and national newspapers may be used to help students gain current perspectives abour contemporary social problems and the debates that occur around proposed solutions. Additionally, television news programs such as " 60 Minutes," or "Meet the Press," may be viewed to increase students' awareness of social problems and the infuence of economics and politics on those problems. Contemporary films may also be used to facilitate students' understanding of social problems, as films provide opportunities for students to empathize and identify with characters (Grodal, 1997). Well selected films may be useful since they ground abstracr social policy concepts in real life contexts enabling students to engage with the subject matter. Put simply, films help put a human face on social problems that may seem abstract, complex, and

Debra Anderson, PhD is assistant professor, School of Social Work, University of Nebraskam Omaha. Carol Langer, PhD is assistant protessor, Department of Social Work, Arizona State University. Rich Furman, PhD is associate professor \& BSW coordinator, College of Health and Human Services, Department of Social Work, University of North Carolina at Charlorte. Kim Bender, MSW is a doctoral student, School of Social Work, University of Texas.

Copyright $\odot 2005$ Adnances in Social Work Vol. 6 No. 2 (Fall 2005) $251-262$. 
overwhelming to students unfamiliar with macro-level social issues.

The purpose of this article is to explore the use of contemporary film in teaching social welfare policy courses. It will do so through three primary methods. First, we discuss the relevance that films have for higher education in general, and social work in particular. Second, we present three fims as case examples, including assignments and exercises used to increase students' understanding and application of social welfare policy concepts. Third, the appropriateness of each of the films is analyzed by applying criteria for film selection and use (Downey, Jackson, Puig, \& Furman, 2003). The final section explores the implications of using film for social work education.

\section{THE USE OF FILM IN HIGHER EDUCATION}

Popular films are widdy viewed by today's young adults. Films often address human behavior and social issues relevant to the helping professions. Due to their wide appeal and ability to intellectually engage college-aged students, several health and mental health disciplines have begun to use popular films in their various curricula.

Psychiatry, for cxample, has used film to instruct medical students and psychiatric trainees regarding cultural awareness. Psychiatry training programs have used films to increase cultural competence by identifying differences and similarities between the culture in the film and the trainee's own culture and by identifying issues relevant to delivering services to this population (Bhugra, 2003).

In addition to culcural competency, the medical field has also advocated for the use of film to teach medical students about intoxication and withdrawal syndromes. In a recent study, more than $90 \%$ of medical students believed that movie clips helped them to identify substance related syndromes and gave them insight into the severity of symptoms (Welsh, 2003).

The nursing field has also embraced the use of film in teaching advanced practice mental health. In a study of master's students' perspectives on the use of film in an on-line course, Raingruber (2003) reports films promore refecrion, arouse emotions and empathy for clients, and are a good way to present both mental health content and introduce ethical dilemmas.

Teaching about psychological disorders in a course entitled "Images of Madness," Fleming, Piedmont, \& Hiam (1990) use fearure length films preceded by lecrure and followed up by class discussion. Student reports at the end of the course showed films realistically portrayed posttraumatic stress syndromes and substance abuse while doing a poorer job regarding eating disorders. Overall, students felt the use of films helped to increase their knowledge about psychological disorders and thinking about mental illness (Fleming, et al., 1990).

Marriage and family therapy counselor education programs use films to help counselors in training to develop skills related to the way they perceive clients, conceprualize problems and execute trearment plans (Higgins \& Dermer, 2001). Gladding (1994) uses films as a form of evaluation in marriage and family courses by asking students to identify family patterns and possible problems in families featured in films. 
Toman and Rak (2000) revicwed the use of film with counselors and found film instruction useful in teaching "diagnosis, counseling theories, interventions and ethics" (p. 1). The authors further report graduate students' follow up questionnaires describe high satisfaction in learning the material, increased engagement in the material and better understanding of counseling field (Toman \& Rak, 2000).

Despite positive reviews for using film in various curricula, caution should be used in implementation. Bhugra (2003) calls for careful use of film as many films may give a socially stercotypical portrayal of different cultures. This is substantiated by nursing students' suggestions that particular attention be paid to distinguishing a film's dramatic portrayal verses real-life portrayal of people's experiences (Raingruber, 2003). The importance of teacher-led discussions and reflection prior to and/or after viewing popular films is noted in the literature (Nugent \& Shaunessy, 2003).

Fearure films should be used to complement lecture and other forms of literary information and not as the sole basis for informing students. For example, students or trainees may over generalize the portrayals of mentally ill characters in films. Identifying the symptoms while recognizing them in the context of entertainment flim is important (Byrne, 2003).

Logistical obstacles should also be addressed by teachers using films. Nursing students reported inconvenience in that films are time consuming to warch or may contain uncomfortable information. Raingruber (2003) suggests giving students a variety of film options from which to choose. Students should be allowed to make educated decisions on the different perspectives certain films might take on a topic and levels of violence/sexual content that fit their comfort levels (Raingruber, 2003).

\section{THE USE OF CONTEMPORARY FILM IN SOCIAL WORK EDUCATION}

While the literature about the use of film in related felds is extensive, the social work literature is less voluminous. However, there is evidence that the profession is recog. nizing the value of film in teaching certain course content, such as adolescent development and social context (Downey, Jackson, Puig, \& Furman, 2003), therapeutic interventions (Vinton \& Harrington, 1994), and social problems (Dressel, 1990).

An exploratory study by Downey, Jackson, Puig, and Furman (2003) confirms the findings of other professions' studies, as students reported positive responses upon viewing two motion pictures depicting mental illness and racism. The authors report over $90 \%$ of students agreed that the film enhanced their learning experience, complemented lecture information, and addressed learning objecrives of the course. Visual learners and traditionally aged students in particular found the use of film the most helpful in illustrating concepts and theories of human behaviors and social problems (Downey, et al. 2003).

Moreover, using contemporary films in human service education allows instructors to make linkages berween the relatively predictable world of the classroom and the more disorderly realities of the practice world (Downey, Jackson, \& Furman, 2002). The authors suggest five characteristics of contemporary film that may account for their relevance in the classroom: films are concrete, providing a physical reality while 
documenting a narrative; films present human and cultural diversity; films invite praxis, combining social and political theory with practice; the complexiry of a film's sroryline leads students to grapple with the reality of multiple approaches to assessment and intervention; and films encourage more active student engagement in the educational process. The authors urge instructors to make certain that each of these five areas is actively attended to by the classroom instructor in order to maximize the educational use of a film. All too often, films are used in a more random manner and are not utilized optimally.

Typically, flms are used as case studies in the classroom, allowing students to develop an empathic connection to characters that may not occur with traditional case studies (Grodal, 1997). Since films are multi-sensory they can stimulate thinking and affect in a more holistic manner than written case-studies. For courses focused on individual and/or family diagnosis and treatment, then, films can be beneficial in introducing students to the complexity of family life in contexts that are different from their own (Pescosolido, 1990).

Given that films have been shown to help students gain skills in conceptualizing problems, diagnosing illnesses, and heightening cultural sensitivity in working with individuals and families, it makes sense that instructors night also use films to help students conceptualize social (as opposed to individual) problems, assess environmental factors, and identify strategies to address these issues. It is arguably more difficult, however, to locate contemporary films that cover macro-level content, including administration, community organization, and social welfare policy. Indeed, a national social work educators' listserv frequently posts questions by faculty members inquiring about film suggestions for macro courses. What is missing from these inquiries, however, are discussions about the knowledge and skills students should gain from vicwing the film and the assignments and exercises that can be used to evaluate students' learning. The following section presents three films and accompanying assignments used by the authors to teach students policy concepts and skills.

\section{FILMS IN SOCIAL WELFARE POLICY COURSES}

\section{Preparation for Viewing a Film:}

Contemporary films that address social problems and/or social policies often include themes that are controversial; indeed, many contain graphic language and/or imagery that can be offensive to some students. Instructors should not only assess their students' readiness for viewing such films, but need to prepare them by discussing the purpose of the film and establishing parameters for the experience. In other words, students should be directed to focus on the substantive content of the film and its relevance to social welfare policy rather than a particular actor or actress in the film. Students should be introduced to the subject matter prior to viewing the film. This can be done through lectures and class discussions - discussing the pros and cons of eligibility rules, for example, prior to viewing a film about poverty. Additionally, having students complete value inventories about social problems prior to viewing the film 
can help them mentally prepare to focus on the policy content.

\section{Viewing Films about Social Welfare Policy:}

Most films that include policy content also include conrent about administration, community development, and community organization. Therefore, the films identified below could be used with equal success in other macro courses. Ulimately, it is up to the instructor to determine how the film helps fulfill the course objectives.

Table 1. Description of Three films with sample discussion questions and areas for assessment

\begin{tabular}{|c|c|c|c|}
\hline $\begin{array}{l}\text { Film } \\
\text { Title } \\
\end{array}$ & Description & Sample Questions & $\begin{array}{c}\text { Student } \\
\text { Assessment }\end{array}$ \\
\hline $\begin{array}{l}\text { Scout's } \\
\text { Honor }\end{array}$ & $\begin{array}{l}\text { Documentary } \\
\text { depicting a Boy } \\
\text { Scout secking to } \\
\text { change policy } \\
\text { restricting gays from } \\
\text { joining or holding } \\
\text { leadership positions } \\
\text { in the Boy Scout } \\
\text { organization. }\end{array}$ & $\begin{array}{l}\text { What were the values that influenced } \\
\text { Steven, his family, and others to take } \\
\text { a stand about the ban on gays in the } \\
\text { Boy Scouts? } \\
\text { How did Steven want eligibility } \\
\text { for membership dctermined? How } \\
\text { did the Boy Scouts want eligibility } \\
\text { determined? } \\
\text { What groundwork occurred before } \\
\text { advocacy began? } \\
\text { What lobbying methods did he use? } \\
\text { Assess the effectiveness of each. } \\
\text { How was Steven changed by this } \\
\text { experience? } \\
\text { How was the national organization } \\
\text { changed by this challenge? }\end{array}$ & $\begin{array}{l}\text { Knowledge: } \\
\text { Discrimination } \\
\text { Gay righrs } \\
\text { legislation } \\
\text { Ecological } \\
\text { perspective } \\
\text { Role of judiciary } \\
\text { Social justice } \\
\text { Policy analysis } \\
\text { framework } \\
\text { Skills: } \\
\text { Advocacy } \\
\text { Lobbying } \\
\text { Campaign } \\
\text { organization } \\
\text { Petition drives } \\
\text { Public speaking } \\
\text { Policy analysis }\end{array}$ \\
\hline
\end{tabular}




\begin{tabular}{|c|c|c|c|}
\hline $\begin{array}{l}\text { Film } \\
\text { Title }\end{array}$ & Description & Sample Questions & $\begin{array}{c}\text { Student } \\
\text { Assessment }\end{array}$ \\
\hline $\begin{array}{l}\text { Losing } \\
\text { Isaiah }\end{array}$ & $\begin{array}{l}\text { A middle class } \\
\text { Caucasian family } \\
\text { fosters and then } \\
\text { adopts an African } \\
\text { American baby, } \\
\text { Three years later, the } \\
\text { baby's bio-mother } \\
\text { (recovering from } \\
\text { drug addiction) } \\
\text { seeks reinstatement } \\
\text { of her parental } \\
\text { rights. The last half } \\
\text { of the film takes } \\
\text { place primarily in } \\
\text { the courtroom. }\end{array}$ & $\begin{array}{l}\text { If social work values include } \\
\text { "commitment[s] to human welfare, } \\
\text { social justice, and individual dignity } \\
\text { (Reamer, } 1987, \text { p. } 801 \text { ), does the social } \\
\text { worker fulfill those values or violate } \\
\text { ethical practice by fostering and } \\
\text { adopting her client? } \\
\text { Compare the adequacy, equity, } \\
\text { and effectiveness of punishment vs } \\
\text { treatment for drug addicted mothers. } \\
\text { Should there be a state of limitations } \\
\text { on one's ability to seek rcinstatement } \\
\text { of parental rights? } \\
\text { Is it cultural genocide to permit cross- } \\
\text { racial adoption? } \\
\text { What is the appropriate role of the } \\
\text { judiciary in adoption decisions? }\end{array}$ & $\begin{array}{l}\text { Knowledge: } \\
\text { Linkages among } \\
\text { social problems, } \\
\text { including drug } \\
\text { abuse, poverty, } \\
\text { substandard } \\
\text { housing, child } \\
\text { abandonment, and } \\
\text { institutional racism } \\
\text { Link between } \\
\text { valucs, ethics, and } \\
\text { professional actions } \\
\text { Child welfare policy } \\
\text { and practice } \\
\text { Relationship } \\
\text { between poor inner- } \\
\text { city neighborhoods } \\
\text { and prevalence of } \\
\text { drug abuse and } \\
\text { crime } \\
\text { U. S. drug policies } \\
\text { and social welfare } \\
\text { Trans-cultural . } \\
\text { foster care and } \\
\text { adoption } \\
\text { Skills: } \\
\text { Cultural } \\
\text { competency } \\
\text { Problem analysis } \\
\text { skills } \\
\text { Policy analysis skills } \\
\text { Identification of } \\
\text { strategies to address } \\
\text { complex social } \\
\text { problems }\end{array}$ \\
\hline
\end{tabular}




\begin{tabular}{|c|c|c|c|}
\hline $\begin{array}{l}\text { Film } \\
\text { Tirle }\end{array}$ & Description & Sample Questions & $\begin{array}{c}\text { Student } \\
\text { Assessment }\end{array}$ \\
\hline $\begin{array}{l}\text { And the } \\
\text { Band } \\
\text { Played } \\
\text { On }\end{array}$ & $\begin{array}{l}\text { Fact-based film } \\
\text { describing the } \\
\text { cvolution of HIV } \\
\text { and AIDs with } \\
\text { respect to the U.S. } \\
\text { Center for Disease } \\
\text { Control's role in } \\
\text { the diagnosis and } \\
\text { treatment of the } \\
\text { disease, as well } \\
\text { as the influence } \\
\text { of the Reagan } \\
\text { Administration's } \\
\text { public policy about } \\
\text { AIDS research and } \\
\text { treatment. }\end{array}$ & $\begin{array}{l}\text { The social problem of HIVIAIDS was } \\
\text { framed differently by the plyysicians, } \\
\text { politicians, victims, etc. Choosing } \\
\text { one group's perspecrive, analyze the } \\
\text { problem of HIV/AIDS. } \\
\text { Apply the following evaluation } \\
\text { criteria to contrast the advantages and } \\
\text { disadvantages of giving cash versus } \\
\text { in-kind benefirs to HIV/AIDS victims: } \\
\text { consumer sovereignty, targer efficiency, } \\
\text { cost-effectiveness, and trade-offs. } \\
\text { What value conflicts were evident } \\
\text { among disease sufferers, researchers, } \\
\text { and administrators? How did these } \\
\text { differences in values and ideology } \\
\text { infuence enritlement and eligibility } \\
\text { decisions? } \\
\text { Accessibility refers to the extent } \\
\text { to which obstacles block entry to } \\
\text { the service delivery network. List } 3 \\
\text { examples of obstacles and idenrify a } \\
\text { solution for each. } \\
\text { Give } 2 \text { examples of how funding } \\
\text { availability and/or constraints } \\
\text { influenced service delivery. } \\
\text { The purpose of policy analysis is to } \\
\text { take action based on your assessment } \\
\text { of the policy. First, take a posirion } \\
\text { about the problem of HIV/AIDS } \\
\text { and write a policy statement. Then, } \\
\text { identify } 2 \text { strategies or tactics you } \\
\text { would use to advocare for this policy. }\end{array}$ & $\begin{array}{l}\text { Knowledge: } \\
\text { Policy fornulation, } \\
\text { implementation, } \\
\text { and evaluation } \\
\text { processes } \\
\text { Impact of power } \\
\text { and wealth on } \\
\text { policy and practice } \\
\text { Role of nedia in } \\
\text { policy process } \\
\text { Role of the U.S. } \\
\text { government in } \\
\text { policy } \\
\text { Skills: } \\
\text { Cultural } \\
\text { competency } \\
\text { Socjal action } \\
\text { Lobbying } \\
\text { Public Speaking } \\
\text { Communiry } \\
\text { organizing }\end{array}$ \\
\hline
\end{tabular}

Described above are three films that ate recommended for use in social welfare policy courses. We provide sample questions that can be used to facilitate class discussion or as individual assignments completed by each student and graded by the instructor. We also identify the knowledge and skills students should be able to demonstrate upon viewing the film and answering the discussion questions (assuming they have also read relevant text material and attended lectures). Please note that the questions and assignments are samples and intended to serve as guides only. 


\section{DISCUSSION}

The research conducred by Downey and colleagues (2003) suggests that films ought to address five areas if they are to be meet course objectives. First, they should engage srudents in the course content and educational process. Second, they should document a narrative concrerely to help students grasp course concepts. Third, they should depict human and cultural diversity without over-generalizing or presenting a socially stereotypical portrayal. Fourth, they should capture the complexity of problems so that students realize that multiple approaches could be implemented. Finally, they should demonstrate praxis by cnabling students to link theoretical concepts to practice. This section examines how each of these five areas is addressed by the three selected films.

The beauty of using film to teach social welfare policy is that, for the many social work students uninterested in or wary about social welfare policy courses, films can interest and even engage them in policy content if the films portray an individual or family suffering from a social problem. Integrating the human component, then, is critical to the successful use of contemporary film. Each of the three films presented here does this. For example, the birth mother in "Losing Isaiah" is depicted as loving her son, but suffering from addiction problems that hamper her ability to care for him, while the foster/adoptive family is shown as compassionate and caring, yet flawed as they neglect one another in their quest to keep Isaiah.

In contrast, Steven Cozza in "Scour's Honor" tends to come across as a superhero in his advocacy efforts. To humanize him, the film-makers show him playing soccer, doing chores, and arguing with his mother - in short, acting like a "normal" adolescent boy. This could empower students to consider ways in which they, too, might take action on policy issues, thus reducing some of their feelings of helplessness and/or hopelessness.

Although "And the Band Played On" is more focused on organizational and national policies, it, too, introduces the human component by following one researcher as he struggles to identify and make sense of an unidentified and potentially deadly virus. Additionally, by flashing the pictures of celebrities who have died of AIDS, this film helps students connect the disease with actors, musicians, authors, and others with whom they may be familiar. In sum, by including the human element, students engage quickly with the social problem and are able to understand how individual problems ofren are also social problems.

Second, films concrerize social problems in a way thar lecture, discussions, and even guest speakers can not. Viewing discrimination in "Scour's Honor," for example, enables the student to see the effects of discrimination on friendships, within neighborhoods, and within the larger community. In a particularly moving example, Steven Cozza's life is threatened becausc he refuses to back down in his quest. In a graphic and arguably more powerful presentation, "Losing Isaiah" portrays the links between drug abuse, poverty, and substandard housing when Isaiah's mother refuses to leave her baby in her public housing tenement while she searches for drugs. Finally, "And the Band Played On" shows people slowly dying from AIDS, suffering from weight loss, open sores, and dementia. While such portrayals can be difficult for students to watch, 
they convey the devastating and real effects that social problems have on individuals, families, organizations, and communitics.

As an added bonus, these films provide an opportunity for instructors to introduce the ecological perspective and systems theory into the social welfare policy course, thus enabling students to understand how the ecological and systems models can be applied to macro pracrice, concepts that can be difficult for beginning social work students to grasp.

Third, although as discassed earlier, instructors should not rely solely on films to teach diversity content, films can be extremely useful in sensitizing students to human and culcural diversity. Of the three films presented here, "Scout's Honor" and "And the Band Played on" address issues of sexual orientation and discrimination and the subsequent impact on policy implementation. "And the Band Played On" also addresses racial, gender, and lifestyle diversity among HIV and AIDS patients, so that students become aware of the extent of the disease's reach.

"Losing Isaiah" also addresses racial diversity as the primary social problem in the film is whether or not cross-racial adoprions are acceptable. Because the film portrays both the biological mother (who is African American) and the adoptive mother (Caucasian) as loving but Hawed, our experience is that students do not stereotype but rather come to appreciate the perspectives of both. Gaining the ability to understand and appreciate nulriple perspectives is an important social work skill, particularly in policy analysis, and this film helps students develop that awareness.

Next, films increase students' awareness of the multiple and complex factors that contribute to social problems; the conficting perspectives about the impact of each contribution; and the multiple approaches that are often used to ameliorate social problems. As a result, students gain an appreciation for opposing viewpoints and power differentials that infuence policy-making. In "Scout's Honor" for example, many of Steven Cozza's friends, along with the national Boy Scouts organization oppose his efforts to change the eligibility policy. Ultimately, they witness the infuence of the U.S. Suprene Court as it upholds the national Boy Scouts' policy restricting gays from membership.

Equally controversial, "Losing Isaiah" displays the opposing viewpoints inherent in cross-racial adoptions. At the heart of this issue is the tension between meeting the culcural identiry needs of the child and the child's need for a permanent home. Despite research which suggests that African American children do not adversely suffer from growing up in white families, many social workers believe that children ought to be placed in families that are the same as their birth culture (Hogan \& Siu, 1988). As a result, this film provides an excellent starting point for students to debate the issue of cultural genocide by comparing the Indian Child Welfare Act of 1978, for example, with research about cross-racial adoptions of African American children.

As a final example, "And the Band Played On" powerfully exposed the polarization that resulted between the Center for Disease Control researchers and their administrator as the former sought to research and treat the disease while the latter was constrained by the Reagan Administration in providing adequate funding. Nor lost on the 
students is the assumption in the early 1980 s that HIV and AIDS occurred primarily in gay communities and that this may have led to the lack of federal funding. In sum, by being exposed to these types of ethical and practical dilemmas, students grapple with determining the most acceptable solution for a social problem while also realizing that every policy intervention is accompanied by unintended consequences.

Fifth and finally, films should demonstrate the concept of praxis - and the three discussed here do that as they enable students to not only ga in lnowledge about policy concepts, but each film also depicts some type of social action - the ultimate purpose of policy analysis (Chambers, 1993). For example, in Scout's Honor, the young protagonist Steven Cozza solicits signatures on peritions, marches in the San Francisco Gay Rights Parade, and appears in public venues to speak about the problem. The biological mother in "Losing Isaiah" finds a social worker who advocates for her by helping her find a job, a home, and an atrorncy so that she can work to get her son back. The fim "And the Band Played On" displays advocacy efforts that include organizing gay men, peritioning city officials, and lobbying the U.S. Congress - each film illustrating a range of policy actions and strategies. By viewing these various approaches, students are exposed to important policy practice skills, which - when provided concrete examples - empower rather than intimidate them.

\section{CONCLUSION}

The use of films in social work education is an important pedagogical practice. Much of the literature on the use of films concentrates on their use in the areas of diversity, mental health issues, and family dynamics. Social welfare policy has historically been a course that generates less enthusiasm among students, largely because they fail to see the relationship of policy to their desire to practice micro-level social work. The goal of this paper has been to show that the use of flims can inject this enthusiasm into the study of social welfare policy by drawing students into a storyline that allows emparhy and the understanding of very complex social problems. Films can illustrate the nature of the relationship between micro- and macro-level social work, and they have the potential to bring abstract policy concepts into a more grounded and focused format. Combined with orher typical pedagogical techniques, the use of films to reach social welfare policy can result in extensive exploration and even original research. Three films have been discussed in this paper. Suggestions for their use and possible discussion questions relative to social welfare policy have been presented. In addition, the necessiries of careful selection of the films and preparation of the class for the film's use have been identified. In addition to those criteria, the following issues must be considered in the selection process: length of the film (to fit the class period); intensity of subject material (as a preparation issue); storyline (appropriate content); era of the film (timclessness or dated); "the hook" (might be actors, situations, provocative focal point, life experiences/identification, or cultural issue); and the type of film (documentary, reality-based, animared, erc.). The result of using films to teach social welfare policy can be an engaging and stimulating classroom experience with long term benefits for students undertaking social work education. 


\section{References}

Anderson, D. K. (in press). Mucking through the swamp; Changing the pedagogy of a social welfare policy course. Joumal of Teaching in Social Work.

Bhugra, D. (2003). Using film and literature for cultural competence training, Psychittric Bulletin, 27, 227-228.

Byme, P. (2003). Commentary (on Bhugra: Using flm and lirerature for cultural competence training and teaching through cinema). Psychiatric Bulletin, 27, 431-432.

Chambers, D. E. (1993). Social policy and social programs: A method for the Practical public policy analyst $\left(2^{\text {nd }}\right.$ ed.). New York: Macmillan Publishing Company.

Dobelstein, A. W. (2003), Social welfare: Policy and antysis ( $3^{\text {si }} \mathrm{ed}$ ). Pacific Grove, CA; Brooks Cole Publishing Co.

Downey, E. P., Jackson, R. L., \& Furman, R. (2002). Using conremporary film in human service education. Human Service Education, 22(1), 65-74.

Downey, E. P., Jackson, R. L., Puig, M. E., \& Furman, R. (2003). Perceptions of efficacy in the use of film in social work education: An exploratory scudy. Social Work Education, 22(4). $401-410$.

Dressel, P. (1990). Films that put social problems into global context. Teaching Sociology, 18, $226-230$.

Fleming, M., Piedmont, R., \& Hiam, C. (1990). Images of madness: Feature films in teaching psychology. Teaching of Pychology, 17(3), 185-187.

Gilbert, N., \& Terrell, P. (2002). Dimensions of social welfare policy ( $5^{\text {th }}$ ed.). Boston, MA: Allyn \& Bacon.

Gladding, S. (1994). Teaching family counseling through the use of fiction. Connselor Edtata tion Supervision, 33(3), 191-201.

Grodal, T. (1997). Moving picture: A new theory of fim genres, feelings, and cognition. Oxford: Clarendon Press.

Higgins, ]. \& Dermer, S. (2001). The use of film in Marriage and Family Counselor education. Counselor Education of Supervision, 40, 182-192.

Hogan, P.T. \& Siu, S. (1988). Minority children and the child welfare system: an historical perspective. Social Work, 33(6), 493-498.

Nugent, S. \& Shaunessy, E. (2003). Using film in teacher training: Viewing the gifted through different lenses. Roeper Review, 25(3), 128-135.

Raingruber, B. (2003). Integrating aestherics inro advanced practice mental health nursing* Commercial fim as a suggested modality. lstues in Mental Health Nursing, 24, 467-495.

Pescosolido, B. (1990). Teaching medical sociology through film: Theoretical perspectives and practical tools. Teaching Sociology $18,337-346$.

Toman, S., 8 Rak, C. (2000). The use of cinema in the Counselor Education Curriculum: Strategies and Outcomes. Counselor Education d Stupervision. 40(2), 105-115.

Vinton, L., \& Harrington, P. (1994). An evaluation of the use of videotape in teaching Empathy. Journal of Teaching in Social Work, 9(2), 71-84.

Welsh, C. (2003), OD's and DT's: Using movies to teach intoxication and withdrawal syndromes to medical students. Academic Psychiatry, 27(3), 182-186. 


\section{Author's Note}

Address correspondence to Debra Anderson, PhD, assistant professor, School of Social Work, University of Nebraska-Omaha, $60^{\text {th }}$ and Dodge Streets, Omaha, NE 68182 0293. e-mail: debranderson@mail.unomaha.edu. 